\title{
暖房時の室内過乾燥に影響する要因解析と温湿度予測 SENSITIVE ANALYSIS FOR EXCESSIVE DRYNESS DURING HEATING AND PREDICTION OF HYGROTHERMAL ENVIRONMENT
}

\author{
尾崎明仁, 小笹(香川) 治美**, 辻丸達憲*** \\ Akihito OZAKI, Harumi (KAGAWA) OZASA and Tatsunori TSUJIMARU
}

\begin{abstract}
Dynamic simulation software based upon detailed building physics called THERB for HAM is used to predict hygrothermal environment of whole building. The accuracy of THERB is verified through the comparison of monitored and calculated values of temperature and humidity of the actual residential buildings. Then sensitive analysis utilizing THERB is performed with a number of factors, such as property, area and thickness of interior materials and so on, which influence indoor humidity, especially excessive dryness during heating. Eleven factors that affect indoor humidity are defined with the extent of the influence by the multiple regression analysis on the basis of the sensitive analysis. It is clarified that the THERB can accurately predict the hygrothermal environment of buildings and the extreme sensitive factors influencing indoor humidity are the moisture generation in rooms, outdoor temperature and humidity, moisture capacity of sorption and desorption materials, water vapour permeance of interior finish and the preset heating temperature.
\end{abstract}

\section{Keywords: hygrothermal environment, combined heat and moisture transfer, excessive dryness, parametric analysis, sorption and desorption 温湿度環境, 熱·水分複合移動, 室内過乾燥, 要因解析, 吸放湿}

\section{1.はじめに}

建築施工技術や空調機器効率の向上により，最近の住宅は室内熱 環境の改善および暖冷房負荷の低減を目指して断熱気密化されてい る。また, 次世代省エネルギー基準および住宅性能表示制度の施行, ならびに温室効果ガス排出量の削堿を目的とした京都議定書の発効 により，住宅の断熱気密化は省エネルギー対策としてますます促進 されている。

しかし，暖房時に室内は乾燥しがちで, 目・鼻腔・咽喉の乾燥, インフルエンザウイルスの繁殖，アレルギー症状（アトピー性皮膚 炎等）の悪化など, 低湿環境に起因する健康障害が報告 ${ }^{4 ） さ れ て い ~}$ る。建築物環境衛生管理基準において室内相対湿度は 40\%〜 70\%に 規定されているが，住宅では特に暖房時に 40\%以下の過乾燥になる ことが頻繁である。

一般に, 過乾燥の緩和には加湿器を使用することが多いが, 結露 等の湿害を助長する危険がある。そこで, 周囲空気の温湿度変動に 応じた吸放湿により室内湿度を適度に維持するパッシブ手法（内装 材の調湿作用の積極的利用）が期待されている。既に, 珪藻土やセ ピオライト等を使用した各種調湿建材が開発され ${ }^{5)}$, 収蔵庫の湿度 管理や住宅の湿害防止 ${ }^{6)}$ などに実用化されている。ただし，吸放湿 は周辺空間と材料内部の熱・水分・空気移動が連成した相変化をと
もなう複合現象であり，作用因子も多いことから，その効果は定性 的に説明される程度で，定量的に評価されているとは言い難い。 本研究では，戸建住宅の温湿度測定および数值シミュレーション により，過乾燥状態を引き起こしやすい暖房時の室内環境と，それ に影響する要因について解析する。同時に，建筑全体の温湿度予測 ツール（熱・水分・空気連成を考慮した住環境解析ソフト）の計算 精度について検証するとともに，暖房時の室内湿度の簡易予測方法 について検討する。

\section{2. 戸建住宅の温湿度測定}

\section{1 住宅の概要}

図 1，図 2 に，測定住宅の $1 \cdot 2$ 階平面と壁体構成を示す。また， 写真 1 に測定住宅の外観と居間の状況を示す。表 1 は測定住宅の断 熱・換気に関する基本属性である。この住宅は 2004 年 12 月に福岡 県筑紫野市に建設された伝統的な湿式構法住宅である。夫婦と子供 2 人が生活しており，暖房にはエアコンとコタツを使用している。 室内には加湿器, 観葉植物など水分の発生源はなく, 室内発湿は生 活行為に限られている。ただし，次節に示す測定期間（12月 4 日〜 6 日）は前日から不在であったため室内発湿はない。また,この期 間は内外屝および空を閉め切り，実験的に居間のみ午前と午後に暖

\footnotetext{
本論文は，本研究に関する既発表論文 ${ }^{1 〜 3)}$ をとに加筆・修正し，まとめたものである。

* 京都府立大学人間環境学部 教授. 工博 Prof., Kyoto Prefectural University, Dr. Eng.

** 北九州市立大学国際環境工学部 EA ·博士 (工学) Engineering Adviser, The University of Kitakyushu, Dr. Eng.

*** システック環境研究所 修士 (工学) $\quad$ SYSTECH Environmental Research Laboratory, M. Eng.
} 


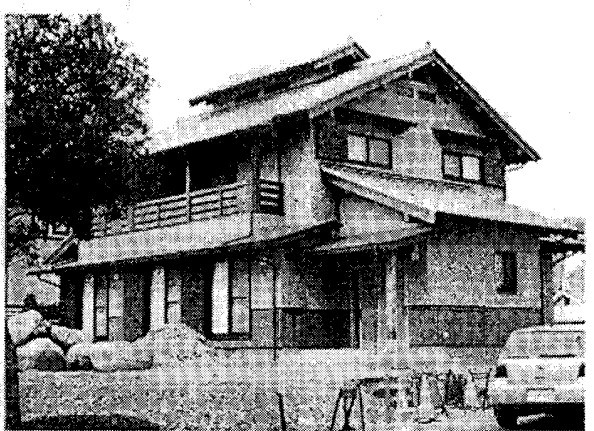

外権

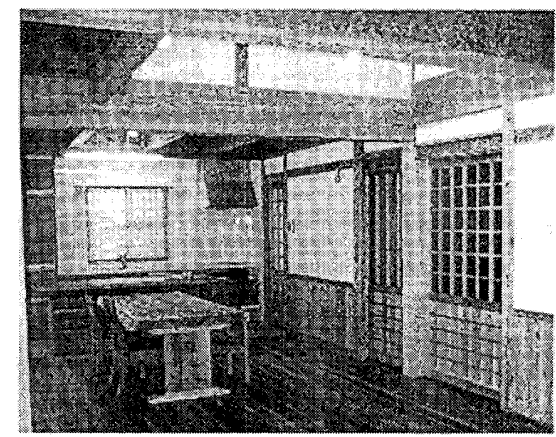

居間
写真 1 測定住宅

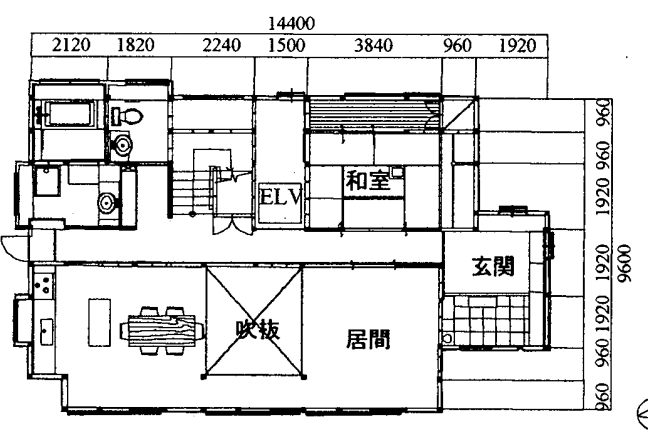

1F 平面図 $\left(116.726 \mathrm{~m}^{2}\right)$

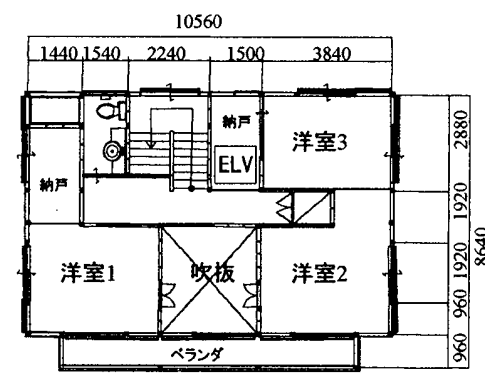

2 階平面図 $\left(76.161 \mathrm{~m}^{2}\right)$
图1 測定住宅の概要（unit: mm）
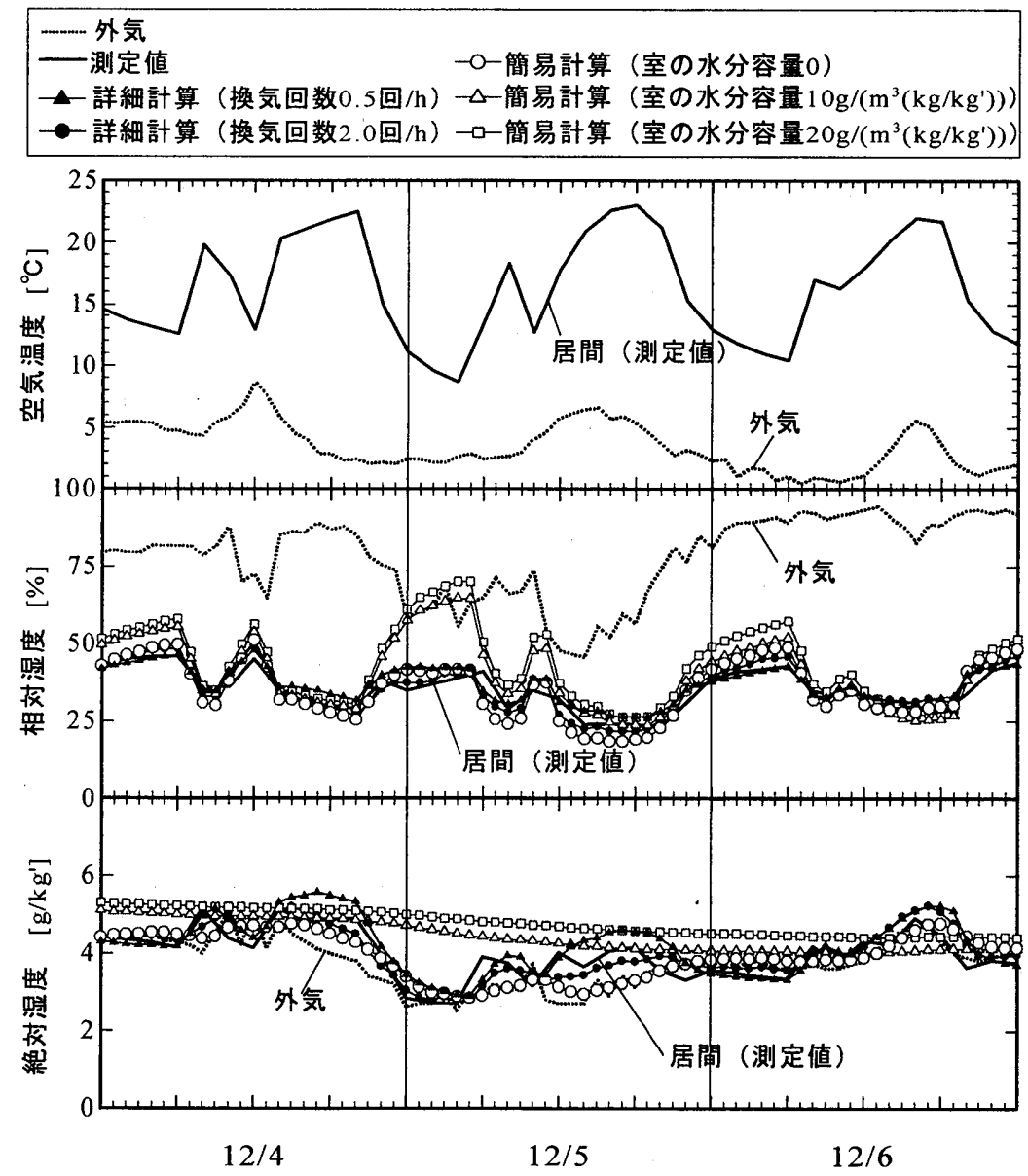

図 3 測定住宅の概要（unit: $\mathrm{mm}$ )
表 1 測定住宅の基本属性

\begin{tabular}{|c|c|c|c|}
\hline \multicolumn{2}{|c|}{ 木造軸組工法2 階建 } & 床面積 $\left(\mathrm{m}^{2}\right)$ & 277 \\
\hline 断熱性能 & 熱損失係数 $(\mathrm{Q}$ 值 $) \mathrm{W} /\left(\mathrm{m}^{2} \cdot \mathrm{K}\right)$ & 2.6 \\
\hline \multirow{2}{*}{ 換気性能 } & \multicolumn{2}{|c|}{ 第 3 種機械換気 } \\
\cline { 2 - 4 } & 換気回数(回 $/ \mathrm{h})$ & 0.52 \\
\hline
\end{tabular}

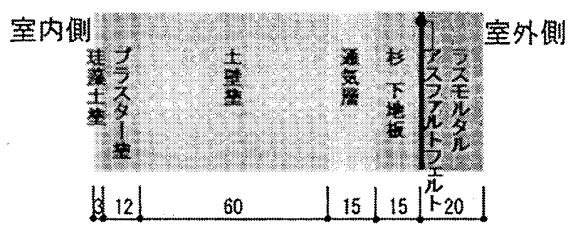

図2 外壁構成(unit: $\mathrm{mm}$ )

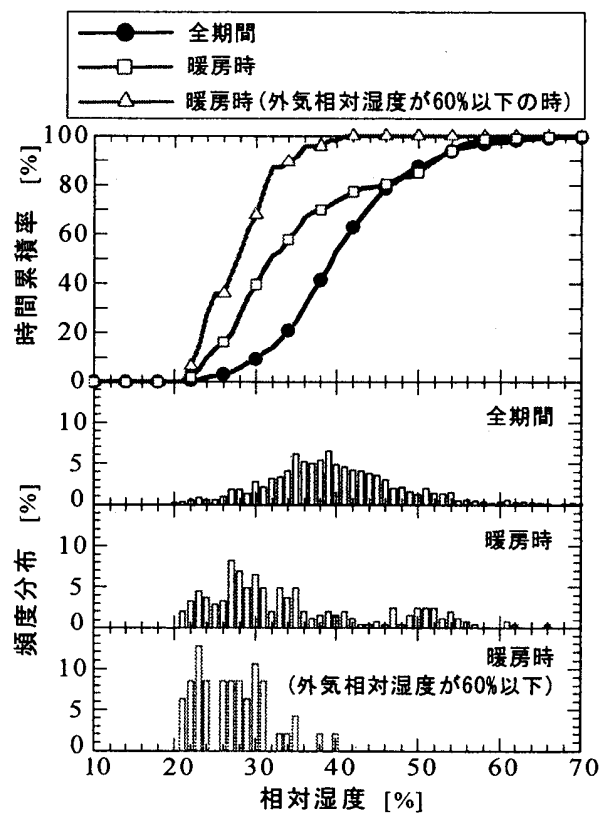

図4 時間累積率之頻度分布(居間)

房した。なお，室内は第 3 種機械換気により常 時換気 $(0.52$ 回 $/ \mathrm{h})$ されている。

\section{2 測定結果}

図3に居間温湿度の測定值 (12月 4 日〜 6 日) を示す。この 3 日間は午前 (6 時頃から平均 2.5 時間）と午後（12 時頃から平均 8 時間）に暖房 している。暖房により室内温度が上昇するにつ れて，室内相対湿度は低下する。5 日午後の暖 房時は $23 \%$ まで低下し過乾燥状態にある。

一方, 室内絶対湿度は温度に追随して暖房開 始後に上昇, 暖房停止後に低下している。図示 した期間は室内発湿がないことから, 室内湿度 変化は躯体等の吸放湿および換気によると考え られる。

図 4 に測定期間 12 月 1 日〜2月 15 日の居間 相対湿度の時間累積率と頻度分布を示す。図中 の各線は，(1)測定した全期間，(2)暖房時（室温 
$18^{\circ} \mathrm{C}$ 以上), (3)暖房時に外気湿度 $60 \%$ 以下の場合の值である。全期 間の頻度分布は低湿域 $20 \%$ から中湿域 $60 \%$ に広く分布している。 方, 暖房時（全期間のうち約 13\%）の頻度分布は $27 \%$ にピークが見 られ，室内相対湿度 $30 \%$ 以下となる時間累積率は約 $40 \%$ にもなる。 暖房時に外気相対湿度が $60 \%$ 以下の場合は, 室内相対湿度 $30 \%$ 以下 となる時間累積率が約 70\%とさらに多くなり，極めて過乾燥状態に なり易い。

\section{3. 室内温湿度予測ツールの検証}

\subsection{THERB for HAM の概要}

THERB (Simulation software of the hygrothermal environment of the residential buildings）は多数室を対象とした室温（空気温度と躯体温 度) ・体感指標 $(\mathrm{PMV}) \cdot$ 熱負荷の動的計算ソフト ${ }^{7)}$ で, 熱・水分複 合移動モデルには P-model 注1) を使用している。室内温湿度は, 躯 体内部の熱・水分移動と連成して, 対流による熱・水分伝達, 換気 による熱・水分移動, 室内の発熱・発湿を基に室空間の熱・水分収 支から求められる。なお, 室内湿度はデフォルトでは P-modelによ

る壁体の吸放湿計算と連成しているが，換気のみ考慮した簡易計算 （壁体の水分容量を室空気に加算して吸放湿の影響を近似）も可能 である。

\subsection{THERB の計算精度}

前節の住宅を対象に，測定值と計算值を比較することにより THERB の計算精度について検証する。

表 2 に計算条件を示す。図 3 に居間温湿度の測定值と計算值（吸 放湿を考慮した詳細計算と簡易計算）を示す。詳細計算は，暖房時 の相対湿度の低下と絶対湿度の上昇および非暖房時の相対湿度の上 昇と絶対湿度の低下（吸放湿現象）を再現し，測定値とよく一致し ている。換気回数を 2.0 回/h とした計算值は 0.5 回 $/ \mathrm{h}$ に比べて相対 湿度の日較差が大きくなるが，両者に顕著な違いは見られない。換 気回数 0.5 回 $/ \mathrm{h}(2.0$ 回 $/ \mathrm{h})$ とした場合の 3 日間の平均絶対誤差は相 対湿度で $3.3 \%(2.8 \%)$ ，絶対湿度で $0.3 \mathrm{~g} / \mathrm{kg}^{\prime}\left(0.2 \mathrm{~g} / \mathrm{kg}^{\prime}\right)$ である。

一方, 水分容量を 0 とした簡易計算は, 換気により室内絶対湿度 が外気絶対湿度に追随し，吸放湿現象を表現できないため相対湿度

表 4 要因(説明変数)と基準值

表 2 精度検証の計算条件

\begin{tabular}{|c|c|c|}
\hline \multirow{4}{*}{$\begin{array}{l}\text { 気 } \\
\text { 委 } \\
\text { 件 }\end{array}$} & 外気温度およひ湿度 & 測定值 \\
\hline & $\begin{array}{l}\text { 直達日射量 } \\
\text { 天空日射量 }\end{array}$ & $\begin{array}{c}\text { 測定值 } \\
\text { (渡邊の式を用いて直散分離) }\end{array}$ \\
\hline & 夜間放射量 & 外気温度湿度より算出 \\
\hline & 風向·風速 & 測定值 \\
\hline & 助走期間 & 10 日間 \\
\hline & 計算啈間間隔 & 15 分 \\
\hline & 室内発湿量 & 生活行為に伴う発湿なし \\
\hline & 換気回数 & 0.5 回 $h$ \\
\hline & 室内温度の初期値 & 測定值 \\
\hline & 体内の温湿度の初期値 & 助走開始時の外気温湿度 \\
\hline
\end{tabular}

表 3 感度解析の計算条件

\begin{tabular}{|c|c|}
\hline 対象室 & 居間·食堂 \\
\hline 対象期間 & 1月と 2月 (冬季) \\
\hline 気象条件 & 昖張アメダスデータ (福岡) \\
\hline 計算時間間隔 & 15 分 \\
\hline 助走期間 & 3 ヶ月間 $(10 \sim 12$ 月 $)$ \\
\hline 目的変数 & $\begin{array}{c}\text { 外気相対湿度が } 60 \% \text { 以下のときの } \\
\text { 室内の平均相対湿度 [\%] }\end{array}$ \\
\hline
\end{tabular}

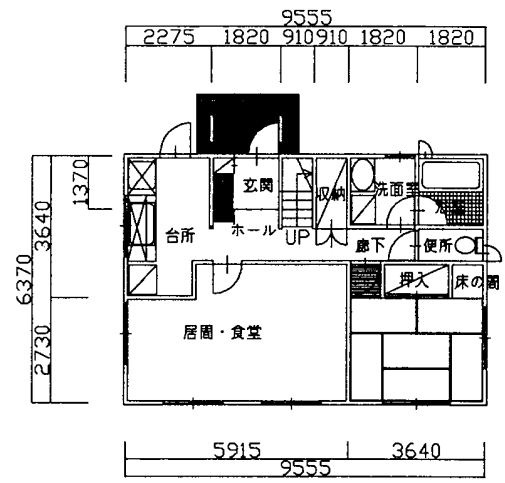

$1 \mathrm{~F}$ 平面図
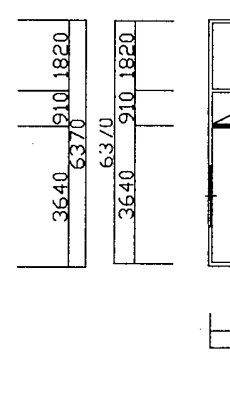

2 階平面图
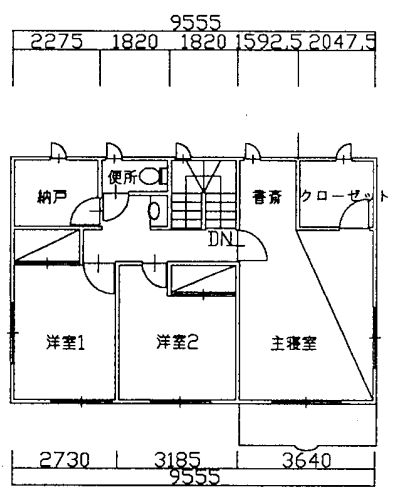

\begin{tabular}{|c|c|c|c|c|c|}
\hline Case & \multicolumn{3}{|c|}{ 要因(説明変数) } & 単位 & 基準値 \\
\hline$A_{1}$ & \multirow{5}{*}{ 离 } & \multirow{2}{*}{$\begin{array}{c}\text { 吸放湿材 } \\
(ハ ゚ ー ラ イ ~ \\
\text { ボード) }\end{array}$} & 水分伝導率 & $\mathrm{kg} /(\mathrm{m} \cdot \mathrm{s} \cdot \mathrm{Pa})$ & $2.8 \mathrm{E}-11$ \\
\hline$A_{2}$ & & & 水分容量 & $\mathrm{kg} /\left(\mathrm{m}^{3} \cdot \mathrm{kJ} / \mathrm{kg}\right)$ & 0.992 \\
\hline B & & \multicolumn{2}{|c|}{$\begin{array}{c}\text { 表面仕上げ材の } \\
\text { 透湿抵抗 } \\
\end{array}$} & $\mathrm{m}^{2} \cdot \mathrm{s} \cdot \mathrm{Pa} \mathrm{kg}$ & 0 \\
\hline C & & \multicolumn{2}{|c|}{ 吸放湿材面積汽積 } & $\mathrm{m}^{2} / \mathrm{m}^{3}$ & 0.727 \\
\hline D & & \multicolumn{2}{|c|}{ 厚办 } & $\mathrm{mm}$ & 12.0 \\
\hline$E$ & \multirow{2}{*}{$\begin{array}{l}\text { 摰 } \\
\text { 態 }\end{array}$} & \multicolumn{2}{|c|}{$\begin{array}{l}\text { 単位床面積あたりの外被 } \\
\text { 断熱性能 (4.1 節参照) }\end{array}$} & $\mathrm{W} /\left(\mathrm{m}^{2} \cdot \mathrm{K}\right)$ & 1.56 \\
\hline $\mathrm{F}$ & & \multicolumn{2}{|c|}{ 換気回数 (気密性能) } & 回/h & 常時 0.5 \\
\hline G & \multirow{3}{*}{$\begin{array}{l}\text { ラ } \\
\text { 方 } \\
\text { 否 } \\
\text { ル }\end{array}$} & \multicolumn{2}{|c|}{$\begin{array}{c}\text { 暖房時間 } \\
\text { (在室時間間欠空調) } \\
\text { 6〜9 時と 17〜22 時 } \\
\text { (Schedule ver.2.0 利用) }\end{array}$} & $\mathrm{h}$ & 10 \\
\hline $\mathrm{H}$ & & \multicolumn{2}{|c|}{ 暖房設定温度 } & ${ }^{\circ} \mathrm{C}$ & 20 \\
\hline $\mathrm{I}$ & & \multicolumn{2}{|c|}{ 室内発湿量/気積 } & $g /\left(h \cdot m^{3}\right)$ & 0 \\
\hline$J$ & 建 & \multicolumn{2}{|c|}{ 建物方位角 } & ND & $\begin{array}{c}0.71^{* 1} \\
=\cos 45^{\circ}\end{array}$ \\
\hline $\mathrm{K}$ & \multirow{2}{*}{ 氮 } & \multicolumn{2}{|c|}{ 平均外気温度 ${ }^{2}$} & ${ }^{\circ} \mathrm{C}$ & 4.58 \\
\hline$L$ & & \multicolumn{2}{|c|}{ 平均外気絶刘湿度 ${ }^{2}$} & $\mathrm{~g} / \mathrm{kg}^{\prime}$ & 2.43 \\
\hline
\end{tabular}


表 5 内装材の水分伝導率 9

\begin{tabular}{|c|c|c|}
\hline Case A & 内装材 & $\begin{array}{c}\text { 水分伝導率 } \\
{[\mathrm{kg} /(\mathrm{ms} . \mathrm{Pa})]}\end{array}$ \\
\hline \hline $\mathrm{A}-1$ & 吸故湿材 1 (へーラ仆) & $2.80 \mathrm{E}-11$ \\
\hline $\mathrm{A}-2$ & 吸放湿材 2 & $2.21 \mathrm{E}-11$ \\
\hline $\mathrm{A}-3$ & 吸放湿材 3 & $1.63 \mathrm{E}-11$ \\
\hline $\mathrm{A}-4$ & 吸放湿材 4 & $1.04 \mathrm{E}-11$ \\
\hline $\mathrm{A}-5$ & パイン & $2.60 \mathrm{E}-13$ \\
\hline $\mathrm{A}-6$ & 土壁 & $2.60 \mathrm{E}-11$ \\
\hline $\mathrm{A}-7$ & 合板 & $5.67 \mathrm{E}-13$ \\
\hline $\mathrm{A}-8$ & セメントモルタル & $4.57 \mathrm{E}-12$ \\
\hline $\mathrm{A}-9$ & コンクリート & $1.15 \mathrm{E}-12$ \\
\hline $\mathrm{A}-10$ & 石亳ボード & $2.13 \mathrm{E}-11$ \\
\hline $\mathrm{A}-11$ & レンガ & $2.60 \mathrm{E}-11$ \\
\hline
\end{tabular}

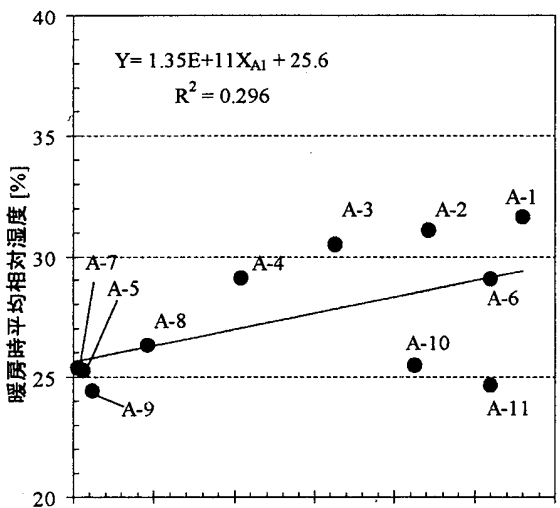

水分伝算率 $[\mathrm{kg} /(\mathrm{m} . \mathrm{s} . \mathrm{Pa})]$

図6内装材の水分枟導率の影響

表 8 室容積あたりの吸放湿材面積

\begin{tabular}{|c|c|c|}
\hline Case C & 吸放湿部位面 & $\begin{array}{c}\text { 面積室容積 } \\
{\left[\mathrm{m}^{2} / \mathrm{m}^{3}\right]}\end{array}$ \\
\hline \hline $\mathrm{C}-1$ & 南 & 0.18 \\
\hline $\mathrm{C}-2$ & 南·東 & 0.35 \\
\hline $\mathrm{C}-3$ & 南·東·北 & 0.48 \\
\hline $\mathrm{C}-4$ & 南·東·北·西 & 0.73 \\
\hline $\mathrm{C}-5$ & 南·東·北·西·天并 & 1.11 \\
\hline
\end{tabular}

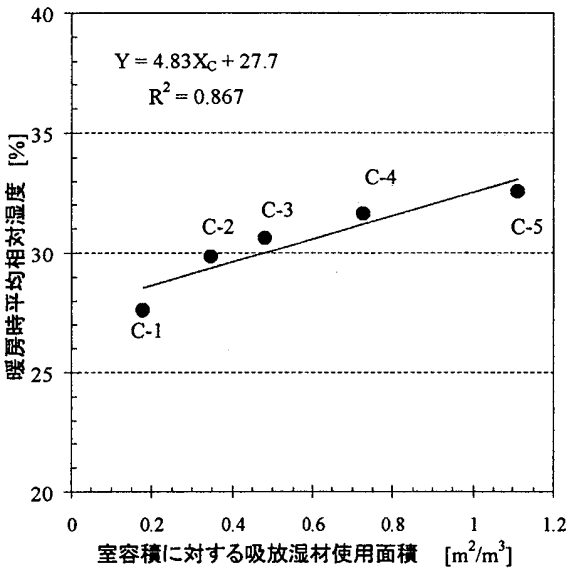

図 9 吸放湿面積の影響
表 6 内装材の水分容量9

\begin{tabular}{|c|c|c|}
\hline Case A & 内装材 & $\begin{array}{c}\text { 水分容量 } \\
{\left[\mathrm{kg} /\left(\mathrm{m}^{3} \cdot(\mathrm{kJ} / \mathrm{kg})\right)\right]}\end{array}$ \\
\hline$A-1$ & 吸放湿材 1 (パーラ仆) & 0.992 \\
\hline$A-2$ & 吸放湿材 2 & 0.773 \\
\hline A-3 & 吸放湿材 3 & 0.553 \\
\hline$A-4$ & 吸放湿材 4 & 0.333 \\
\hline$A-5$ & パイン & 0.213 \\
\hline$A-6$ & 土壁 & 0.191 \\
\hline A-7 & 合板 & 0.184 \\
\hline$A-8$ & セメントモルタル & 0.114 \\
\hline A-9 & コンクリート & 0.0906 \\
\hline$A-10$ & 石亳ボード & 0.01754 \\
\hline A-11 & レンガ & 0.00767 \\
\hline
\end{tabular}

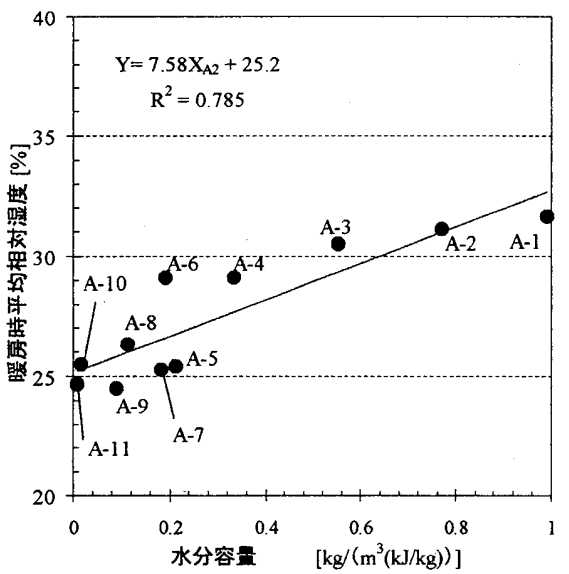

図7 内装材の水分容量の影響

表 9 吸放湿材の厚さ

\begin{tabular}{|c|c|c|}
\hline Case D & 吸放湿材の厚さ & 厚さ $[\mathrm{mm}]$ \\
\hline \hline $\mathrm{D}-1$ & $3 \mathrm{~mm}$ & 3.0 \\
\hline $\mathrm{D}-2$ & $6 \mathrm{~mm}$ & 6.0 \\
\hline $\mathrm{D}-3$ & $9 \mathrm{~mm}$ & 9.0 \\
\hline $\mathrm{D}-4$ & $12 \mathrm{~mm}$ & 12.0 \\
\hline $\mathrm{D}-5$ & $15 \mathrm{~mm}$ & 15.0 \\
\hline
\end{tabular}

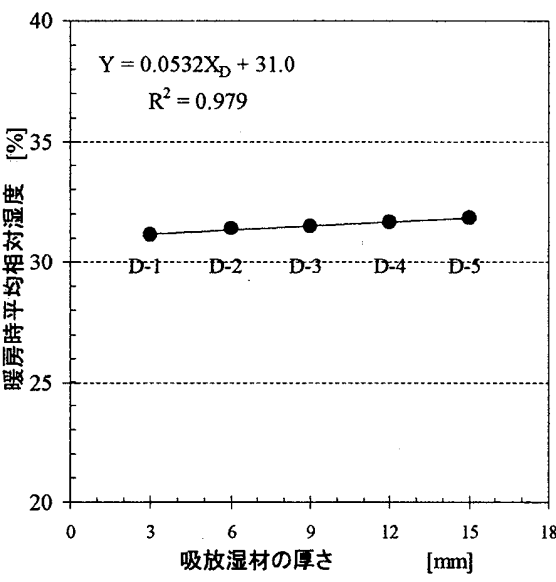

图 10 吸放湿材の厚さの影響
表 7 表面仕上げ材を含む見かけの水分䛃達抵抗

\begin{tabular}{|c|c|c|}
\hline Case B & $\begin{array}{c}\text { 表面仕上げ材の } \\
\text { 透湿抵抗 } \\
{\left[\mathrm{m}^{2} . s . P a \mathrm{~kg}\right]}\end{array}$ & $\begin{array}{c}\text { 表面仕上げ材 } \\
\text { を含む } \\
\text { 見かけの } \\
\text { 水分伝達抵抗 } \\
{\left[\mathrm{m}^{2} . \mathrm{s} . \mathrm{Pa} / \mathrm{kg}\right]}\end{array}$ \\
\hline B-1 & 0 & $2.40 \mathrm{E}+07$ \\
\hline B-2 & $2.17 \mathrm{E}+11$ & $4.10 \mathrm{E}+08$ \\
\hline B-3 & $1.20 \mathrm{E}+12$ & $1.39 \mathrm{E}+09$ \\
\hline B-4 & $2.17 \mathrm{E}+12$ & $2.37 \mathrm{E}+09$ \\
\hline B-5 & $2.87 \mathrm{E}+12$ & $3.06 \mathrm{E}+09$ \\
\hline
\end{tabular}

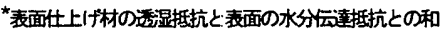

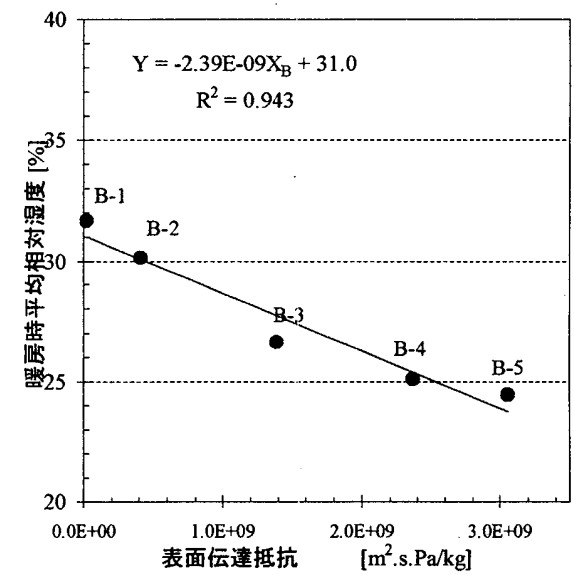

図8 表面仕上げ材を含む見かけの水分伝達抵抗の影禦

表 10 単位床面積海たりの外被断熱性能

\begin{tabular}{|c|c|c|}
\hline Case E & $\begin{array}{c}\text { 断熱材厚さ/窓仕 } \\
\text { 様 }\end{array}$ & $\begin{array}{c}\text { 外皮断熱性 } \\
\text { 能 } \\
{\left[\mathrm{W} /\left(\mathrm{m}^{2} \cdot \mathrm{K}\right)\right]}\end{array}$ \\
\hline$E-1$ & 100mm/low-eがラス & 1.30 \\
\hline $\mathrm{E}-2$ & 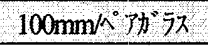 & 1.56 \\
\hline$E-3$ & 50mm/low-eガラス & 1.59 \\
\hline$E-4$ & $50 \mathrm{~mm} / \wedge^{\circ} \Upsilon$ Tがス & 1.84 \\
\hline$E-5$ & 50mm方バル゙ラス & 2.63 \\
\hline
\end{tabular}

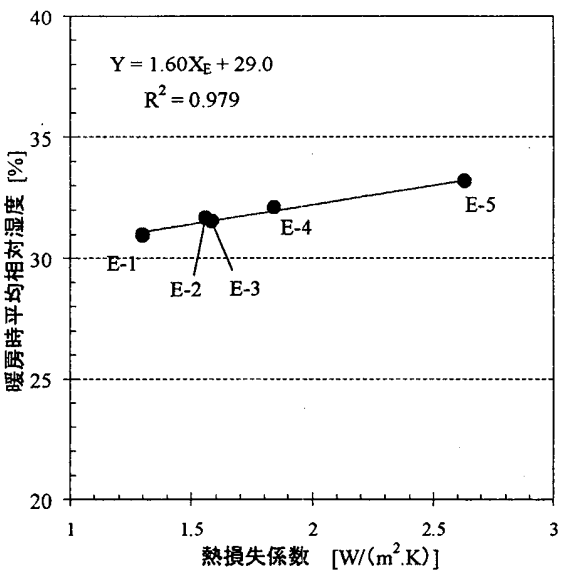

图 11 単位床面積あたりの外被断熱性能の影響 
表 11 換気回数

\begin{tabular}{|c|c|c|}
\hline Case $F$ & 換気回数 & [回 $/ h]$ \\
\hline$F-1$ & 0.25 回 $/ h$ & 0.25 \\
\hline$F-2$ & 0.5 回 $/ h$ & 0.50 \\
\hline$F-3$ & 1 回 $/ h$ & 1.0 \\
\hline$F-4$ & 2 回 $/ h$ & 2.0 \\
\hline$F-5$ & 3 回 $h$ & 3.0 \\
\hline
\end{tabular}

\begin{tabular}{|c|c|c|}
\hline Case G & 暖房時間 & {$[h]$} \\
\hline G-1 & 6 時間 & 6 \\
\hline G-2 & 8 時間 & 8 \\
\hline G-3 & 10 時間 & 10 \\
\hline G-4 & 12 時間 & 12 \\
\hline G-5 & 14 時間 & 14 \\
\hline
\end{tabular}

\begin{tabular}{|c|c|c|}
\hline Case $\mathrm{H}$ & 暖房設定温度 & {$\left[{ }^{\circ} \mathrm{C}\right]$} \\
\hline \hline $\mathrm{H}-1$ & $16{ }^{\circ} \mathrm{C}$ & 16 \\
\hline $\mathrm{H}-2$ & $18{ }^{\circ} \mathrm{C}$ & 18 \\
\hline $\mathrm{H}-3$ & $20{ }^{\circ} \mathrm{C}$ & 20 \\
\hline $\mathrm{H}-4$ & $22{ }^{\circ} \mathrm{C}$ & 22 \\
\hline $\mathrm{H}-5$ & $24{ }^{\circ} \mathrm{C}$ & 24 \\
\hline
\end{tabular}

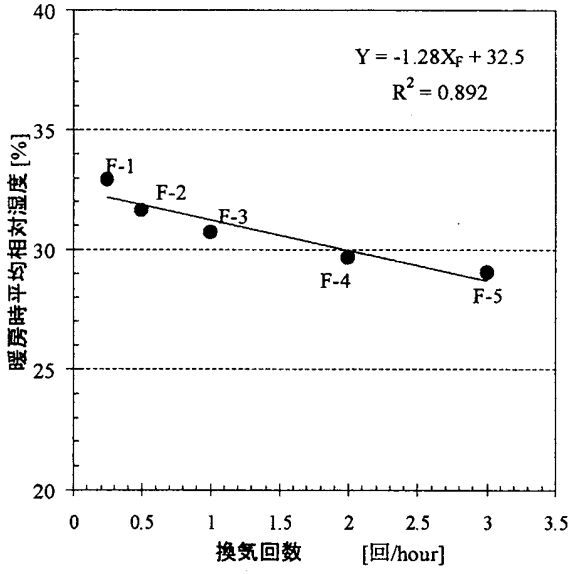

図 12 換気回数の影響

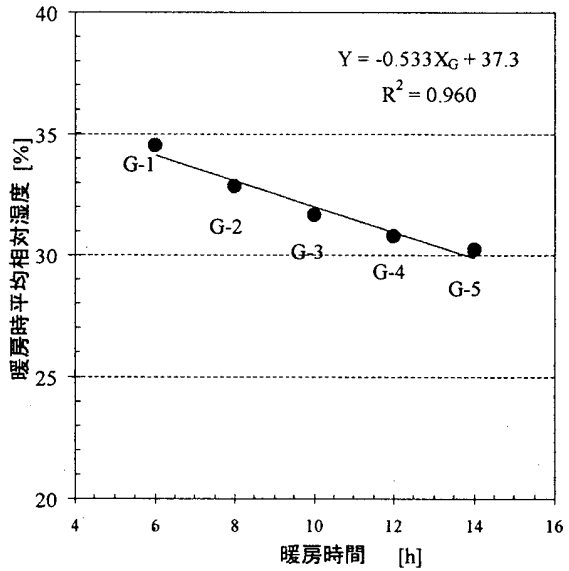

図 13 暖房時間の影響

表 15 建物方位角(南: $0^{\circ}$ )

\begin{tabular}{|c|c|c|}
\hline Case I & 室内発湿量 & $\begin{array}{c}\text { 発湿量庢容積 } \\
{\left[\mathrm{g} /\left(\mathrm{hm}^{3}\right)\right]}\end{array}$ \\
\hline \hline $\mathrm{l}-1$ & $0 \mathrm{gh}$ & 0.00 \\
\hline $\mathrm{I}-2$ & $30 \mathrm{~g} / \mathrm{h}$ & 0.54 \\
\hline $\mathrm{H}-3$ & $60 \mathrm{~g} \mathrm{~h}$ & 1.07 \\
\hline $\mathrm{I}-4$ & $90 \mathrm{~g} / \mathrm{h}$ & 1.61 \\
\hline $\mathrm{l}-5$ & $120 \mathrm{~g} / \mathrm{h}$ & 2.14 \\
\hline
\end{tabular}

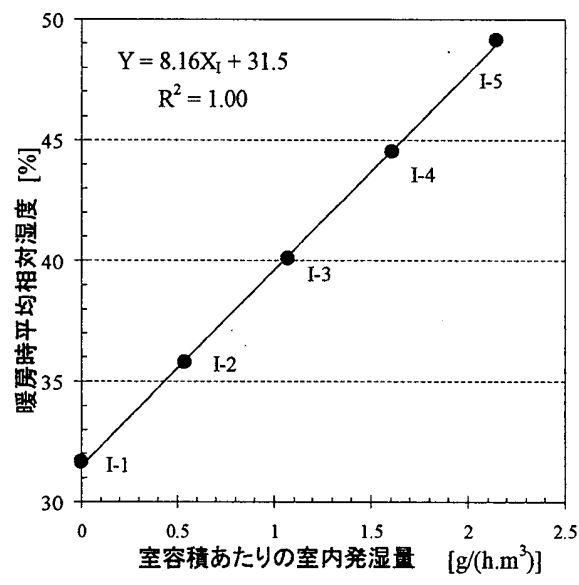

図15 室内発湿量の影鄉

\begin{tabular}{|c|c|c|}
\hline Case J & 建物方位角 & $\cos \theta$ [ND] \\
\hline \hline J-1 & 南 $\left(0^{\circ}\right)$ & 1.00 \\
\hline J-2 & 南西 $\left(45^{\circ}\right)$ & 0.71 \\
\hline J-3 & 西 $\left(90^{\circ}\right)$ & 0.00 \\
\hline J-4 & 北西 $\left(135^{\circ}\right)$ & -0.71 \\
\hline J-5 & 北 $\left(180^{\circ}\right)$ & -1.00 \\
\hline J-6 & 北東 $\left(-135^{\circ}\right)$ & -0.71 \\
\hline J-7 & 東 $\left(-90^{\circ}\right)$ & 0.00 \\
\hline J-8 & 南東 $\left(-45^{\circ}\right)$ & 0.71 \\
\hline
\end{tabular}

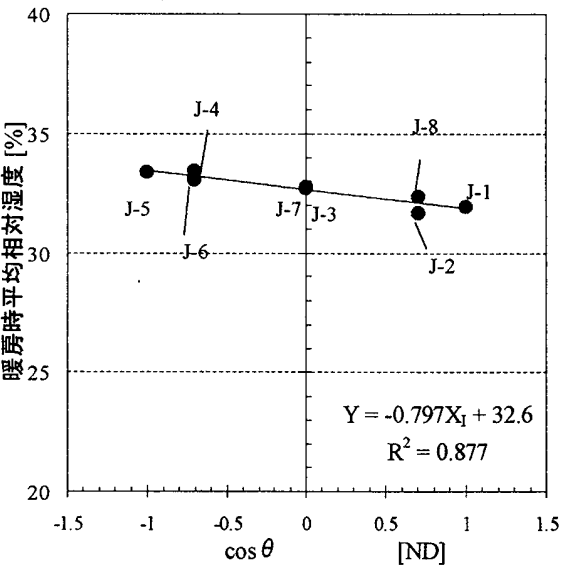

図16 建物方位角の影響

\begin{tabular}{|c|c|c|}
\hline Case $\mathrm{L}$ & 気象条件 & 平均湿度 $\left[\mathrm{g}^{\mathrm{kg}} \mathrm{kg}^{\prime}\right]$ \\
\hline \hline $\mathrm{L}-1$ & $-0.5 \mathrm{~g} / \mathrm{kg}^{\prime}$ & 2.68 \\
\hline $\mathrm{L}-2$ & $\pm 0 \mathrm{~g} \mathrm{~kg}^{\prime}$ & 2.43 \\
\hline $\mathrm{L}-3$ & $+0.5 \mathrm{~g} / \mathrm{kg}^{\prime}$ & 2.23 \\
\hline $\mathrm{L}-4$ & $+1.0 \mathrm{~g} / \mathrm{kg}^{\prime}$ & 2.02 \\
\hline
\end{tabular}

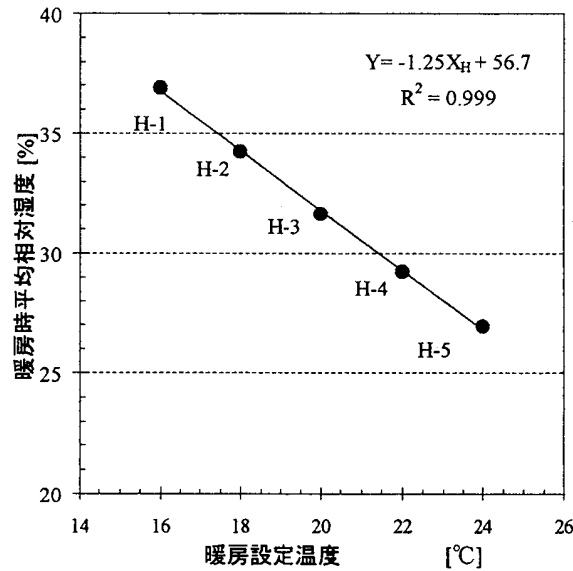

図 14 暖房設定温度の影響

表 16 気象条件(外気温度)

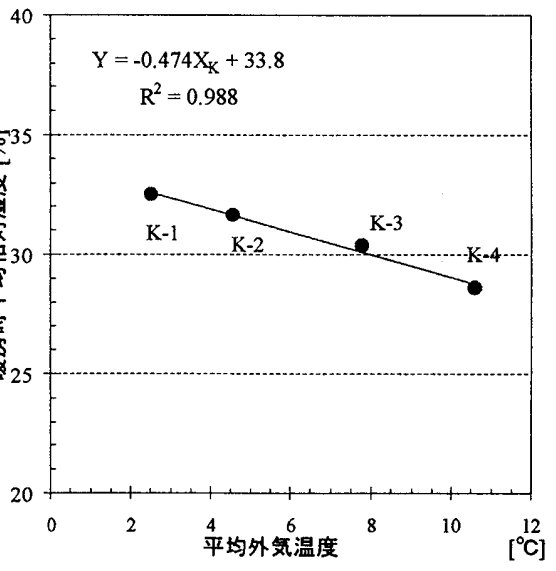

図 17 外気温度の影響 
の日較差が大きくなる。水分容量を 10 あるいは $20 \mathrm{~g} /\left(\mathrm{m}^{3} \cdot \mathrm{kg} / \mathrm{kg}\right)$ とし た簡易計算は，水分容量を 0 とした場合に比べて絶対湿度の変動が 緩慢になる。暖房時は測定值を概ね捕捉するものの, 絶対湿度変動 が少ないため非暖房時は高湿となり大きな誤差を生じている。

\section{4. 室内湿度に影響する各種要因の感度解析}

本節では, 暖房時の室内過乾燥の緩和を目的として，数値シミュ レーションにより建築全体の温湿度環境を予測し，室内湿度に影響 する要因について解析する。各種要因（入力値）を説明変数，室内
相対湿度 (計算結果) を目的変数としてパラメータ感度解析および 重回帰分析を行い，室内過乾燥の改善に効果ある要因について考察 する。

\section{1 建物モデルの概要と計算条件}

図 5 に計算に使用した建物モデルの平面図と外壁構成を示す ${ }^{8)}$ 。 建物モデルの熱損失係数は $2.51\left[\mathrm{~W} / \mathrm{m}^{2} \cdot \mathrm{K}\right]$ で，次世代省エネルギー 基準の第III第IV地域相当であるが，断熱性能と気密性能は別個の 要因と考え，表 4 には，本来の熱損失係数から換気の影響を除いた
表 17 気象条件(外気絶対湿度)

\begin{tabular}{|c|c|c|}
\hline Case L & 気象条件 & 平均湿度 [g/kg] \\
\hline \hline $\mathrm{L}-1$ & $-0.5 \mathrm{~g} / \mathrm{kg}^{\prime}$ & 2.68 \\
\hline $\mathrm{L}-2$ & $\pm 0 \mathrm{~g} / \mathrm{kg}^{\prime}$ & 2.43 \\
\hline $\mathrm{L}-3$ & $+0.5 \mathrm{~g} / \mathrm{kg}^{\prime}$ & 2.23 \\
\hline $\mathrm{L}-4$ & $+1.0 \mathrm{~g} / \mathrm{kg}^{\prime}$ & 2.02 \\
\hline
\end{tabular}

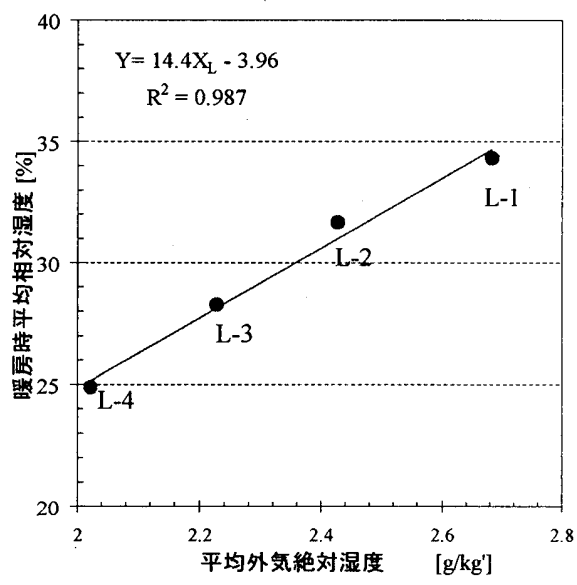

図 18 外気湿度の影響

\begin{tabular}{|c|c|c|c|c|c|c|c|}
\hline \multirow{5}{*}{\multicolumn{2}{|c|}{ 重回帰分析 }} & \multicolumn{3}{|c|}{ 重相関係数 $R$} & \multicolumn{3}{|c|}{0.989} \\
\hline & & \multicolumn{3}{|c|}{ 重決定係数 $R^{2}$} & \multicolumn{3}{|c|}{0.978} \\
\hline & & \multicolumn{3}{|c|}{ 自由度調整済み決定保数 $\hat{R}^{2}$} & \multicolumn{3}{|c|}{0.971} \\
\hline & & \multirow{2}{*}{\multicolumn{3}{|c|}{$\begin{array}{l}\text { AIC } \\
\tilde{T} \text {-夕数 }\end{array}$}} & \multicolumn{3}{|c|}{1.54} \\
\hline & & & & & \multicolumn{3}{|c|}{54} \\
\hline \multicolumn{2}{|c|}{ 分散分析の検証 } & \multicolumn{3}{|c|}{$P$ 値(有意確率) } & \multicolumn{3}{|c|}{ 9.09E-31 <有意水準(5\%) } \\
\hline \multirow{2}{*}{\multicolumn{3}{|c|}{ Case }} & \multirow{2}{*}{ 偏回帰係数 } & \multicolumn{2}{|c|}{ 偏回䀟係数の検定 } & \multirow{2}{*}{\multicolumn{2}{|c|}{$\begin{array}{c}\text { 標準化骗回帰係数 } \\
\text { (加コ内は影滓順) }\end{array}$}} \\
\hline & & & & $\mathrm{F}$ 值 & P値 & & \\
\hline \multicolumn{3}{|c|}{ 切片 } & 25.6 & - & - & \multicolumn{2}{|c|}{ - } \\
\hline$A_{1}$ & \multicolumn{2}{|c|}{ 水分伝遵率 } & $4.73 \mathrm{E}+10$ & 4.05 & $5.06 \mathrm{E}-02$ & 0.052 & (10) \\
\hline$A_{2}$ & \multicolumn{2}{|c|}{ 水分容量 } & 5.53 & 94.5 & $2.60 \mathrm{E}-12$ & 0.309 & (4) \\
\hline B & \multicolumn{2}{|c|}{$\begin{array}{c}\text { 表面仕上げ材を含む } \\
\text { 見かけの水分伀達抵抗 }\end{array}$} & $-2.71 \mathrm{E}-09$ & 186.5 & $4.81 \mathrm{E}-17$ & -0.334 & (5) \\
\hline C & \multicolumn{2}{|c|}{ 吸放湿面皘/室容積 } & 5.57 & 31.8 & $1.32 \mathrm{E}-06$ & 0.137 & (7) \\
\hline$E$ & \multicolumn{2}{|c|}{$\begin{array}{c}\text { 単位面積あたりりの } \\
\text { 外被断熱性能 }\end{array}$} & 1.41 & 4.16 & $4.78 \mathrm{E}-02$ & 0.049 & (11) \\
\hline$F$ & \multicolumn{2}{|c|}{ 換気回数 } & -1.22 & 20.4 & $5.04 \mathrm{E}-05$ & -0.110 & (8) \\
\hline G & \multicolumn{2}{|c|}{ 暖房時間 } & $-4.83 \mathrm{E}-01$ & 15.5 & $2.99 \mathrm{E}-04$ & -0.095 & (9) \\
\hline $\mathrm{H}$ & \multicolumn{2}{|c|}{ 暖房設定温度 } & -1.25 & 103.6 & $6.57 \mathrm{E}-13$ & -0.246 & (6) \\
\hline 1 & \multicolumn{2}{|c|}{ 室内発湿量 } & 8.00 & 833.6 & $2.50 \mathrm{E}-29$ & 0.706 & (1) \\
\hline $\mathrm{K}$ & \multicolumn{2}{|c|}{ 外気温度 } & -2.20 & 118.8 & 8.01E-14 & -0.485 & (2) \\
\hline $\mathrm{L}$ & \multicolumn{2}{|c|}{ 外気絶対湿度 } & 13.86 & 100.7 & $1.01 \mathrm{E}-12$ & 0.444 & (3) \\
\hline
\end{tabular}

表 19 検証のための条件と計算結果

\begin{tabular}{|c|c|c|c|c|c|c|c|c|}
\hline Case & 対象室 & 気象 & \multicolumn{2}{|c|}{ 変更項目 } & 単位 & $\begin{array}{l}\text { THERB の } \\
\text { 結果Y' [\%] }\end{array}$ & $\begin{array}{c}\text { 重回熳式(1)の } \\
\text { 結果Y[\%] }\end{array}$ & $\begin{array}{c}\text { 誤差[\%] } \\
Y^{\prime}-Y\end{array}$ \\
\hline$A^{\prime}-1$ & 洋室 1 & \multirow{16}{*}{ 福岡 } & \multirow{2}{*}{\multicolumn{3}{|c|}{ 基準値(表4参照) }} & 33.4 & 30.9 & 2.5 \\
\hline$A^{\prime}-2$ & 和室 & & & & & 34.1 & 30.4 & 3.7 \\
\hline & & & 水分伝導率 & $2.13 \mathrm{E}-11$ & $\mathrm{~kg} /(\mathrm{m} \cdot \mathrm{s} \cdot \mathrm{Pa})$ & & & \\
\hline$A^{A}-3$ & 洋至1 & & 水分容量 & 0.0175 & $\mathrm{~kg} /\left(\mathrm{m}^{3}(\mathrm{~kJ} / \mathrm{kg})\right)$ & 27.3 & 25.4 & 1.9 \\
\hline$A^{\prime} A$ & & & 水分伝䢙率 & 2.13E-11 & $\mathrm{kg} /(\mathrm{m} \cdot \mathrm{s} \cdot \mathrm{Pa})$ & & & \\
\hline$A-4$ & 机至 & & 水分容量 & 0.0175 & $\mathrm{~kg} /\left(\mathrm{m}^{3}(\mathrm{~kJ} / \mathrm{kg})\right)$ & 27.2 & 25.0 & 2.2 \\
\hline$C^{\prime}-1$ & 洋室 1 & & \multirow{2}{*}{ 面積/室容積 } & \multirow{2}{*}{0.175} & \multirow{2}{*}{$\mathrm{m}^{2} / \mathrm{m}^{3}$} & 28.9 & 27.4 & 1.5 \\
\hline$C^{\prime}-2$ & 和室 & & & & & 30.3 & 27.0 & 3.3 \\
\hline$F-1$ & 洋室 1 & & \multirow{2}{*}{ 換気回数 } & \multirow{2}{*}{2} & \multirow{2}{*}{ 回h } & 31.0 & 29.1 & 2.0 \\
\hline F-2 & 和室 & & & & & 31.2 & 28.6 & 2.6 \\
\hline$G^{\prime}-1$ & 洋室 1 & & \multirow{2}{*}{ 暖房時間 } & \multirow{2}{*}{6} & \multirow{2}{*}{$\mathrm{h}$} & 36.8 & 33.1 & 3.7 \\
\hline$G^{\prime}-2$ & 和室 & & & & & 37.8 & 32.7 & 5.1 \\
\hline$H^{\prime}-1$ & 洋室 1 & & \multirow{2}{*}{ 暖房設定温度 } & \multirow{2}{*}{16} & \multirow{2}{*}{${ }^{\circ} \mathrm{C}$} & 38.9 & 35.9 & 3.0 \\
\hline$H^{\prime}-2$ & 和室 & & & & & 40.4 & 35.4 & 5.0 \\
\hline $\mathrm{I}^{\prime}-1$ & 洋室1 & & \multirow{2}{*}{ 室内発湿量 } & \multirow{2}{*}{1.48} & \multirow{2}{*}{$g /\left(h \cdot m^{3}\right)$} & 45.4 & 42.8 & 2.6 \\
\hline$P-2$ & 和室 & & & & & 44.7 & 39.5 & 5.2 \\
\hline \multirow[b]{2}{*}{$M^{\prime}-1$} & \multirow[b]{2}{*}{ 洋室 1} & \multirow{4}{*}{ 東京 } & 平均外気温度 & 6.41 & ${ }^{\circ} \mathrm{C}$ & \multirow[b]{2}{*}{25.5} & \multirow[b]{2}{*}{24.4} & \multirow[b]{2}{*}{1.1} \\
\hline & & & 平均外気絶対湿度 & 2.25 & $\mathrm{~g} / \mathrm{kg}^{\prime}$ & & & \\
\hline \multirow{2}{*}{$M^{\prime}-2$} & \multirow{2}{*}{ 和室 } & & 平均外気温度 & 6.41 & ${ }^{\circ} \mathrm{C}$ & \multirow[b]{2}{*}{27.0} & \multirow{2}{*}{23.9} & \multirow[b]{2}{*}{3.1} \\
\hline & & & 平均外気絶対湿度 & 2.25 & $\mathrm{~g} / \mathrm{kg}^{\prime}$ & & & \\
\hline \multirow{2}{*}{ M'3 } & \multirow{2}{*}{ 洋室 1} & \multirow{4}{*}{ 大阪 } & 平均外気温度 & 6.17 & ${ }^{\circ} \mathrm{C}$ & & & \\
\hline & & & 平均外気絶対湿度 & 2.62 & $\mathrm{~g} / \mathrm{kg}^{\prime}$ & 33.5 & 30.0 & 3.5 \\
\hline$M^{\prime}-4$ & 和室 & & 平均外気温度 & 6.17 & ${ }^{\circ} \mathrm{C}$ & & & \\
\hline$M-4$ & 机逵 & & 平均外気紨対湿度 & 2.62 & $\mathrm{~g} / \mathrm{kg}^{\prime}$ & 32.4 & 29.6 & 2.8 \\
\hline
\end{tabular}




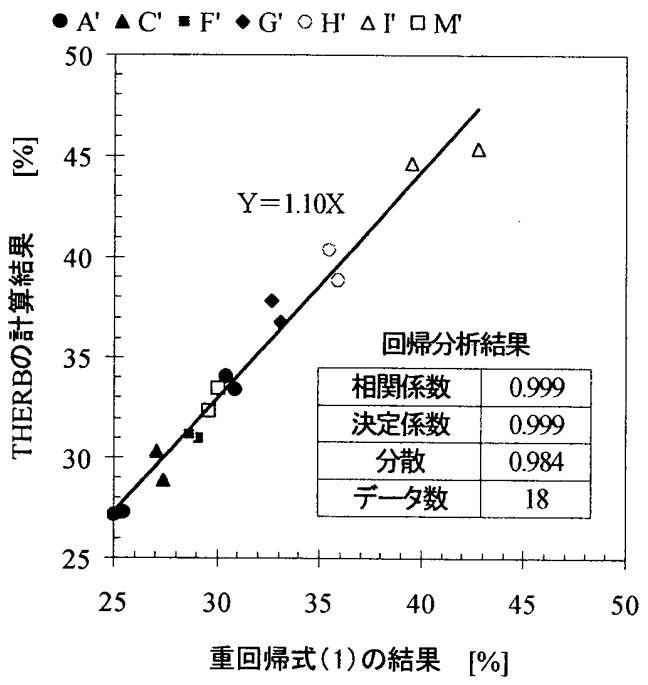

図 19 簡易計算結果と詳細計算結果の比較

值 $1.56\left[\mathrm{~W} / \mathrm{m}^{2} \cdot \mathrm{K}\right]$ を記している。表 3 に計算条件, 表 4 に各種要因 の基準条件を示す。冬季（1月２月）の暖房時において, 室内過乾 燥の生じやすい外気相対湿度が $60 \%$ 以下のときを解析条件とする。 なお, 解析対象室は居間・食堂とし, 暖房時の平均室内相対湿度を 目的変数とする。

\section{2 室内湿度への各種要因の影響}

室内温湿度は, 気象, 建築材料, 建物熱性能, 空調 - 換気設備, 生活スケジュールなどの各種要因に影響される。ここでは, (A) 吸 放湿材の物性值（内装材の水分伝導率と水分容量），(B) 表面仕上 げ材を含む見かけの水分伝達抵抗，(C) 吸放湿材の気積あたりの面 積，（D）吸放湿材の厚み，（E）単位面積あたりの外被断熱性能, （F）換気回数，（G）暖房時間，(H) 暖房設定温度，（I）室内発 湿量, (J ) 建物方位角, (K) 外気温度, (L) 外気相対湿度を室内 湿度に影響する要因（説明変数）として感度解析を行う。

図 6〜18 と表 5 17 に暖房時の室内平均相対湿度と各要因の相関 関係を示す。室内湿度に対して，「水分伝導率・水分容量・吸放湿材 面積・単位面積あたりの外被断熱性能・室内発湿量・外気絶対湿度」 は正の相関, 表面仕上げ材を含む見かけの水分伝達抵抗・換気回数・ 暖房時間・暖房設定温度・外気温度」は負の相関となる。室内発湿 量は室内湿度へ最も大きく影響し，一方，吸放湿材の厚さ之建物方 位角は影響が少ない。

\section{3 室内湿度と各種要因の重回帰分析}

感度解析の結果をもとに, 感度の鈍いケース $\mathrm{D}, \mathrm{J}$ (吸放湿材の 厚さと建築方位角) を除く 11 要因を説明変数 $X$, 室内平均相対湿度 $Y[\%]$ を目的変数（ただし，室内過乾燥の著しい外気相対湿度が $60 \%$ 以下のとき）として重回帰分析 ${ }^{10)}$ を行う。各要因は室内湿度 に対して非線形に影響していると考えられるが，説明変数は目的変 数と相関関係にあるものを採用すべきであるため，予め多重共線性 の有無について診断している注2)。

表 18 に重回帰分析の結果, 式（1）に重回帰式（各要因を $X_{B}$ の ように記述）を示す。重相関係数は 0.989 で, 重決定係数と自由度 調整済み決定係数がほぼ同じ值であること，P 值 (有意確率) が有
意水準（5\%）未満であることなどから，重回帰分析の結果は十分な 信頼性を有している注3）。目的変数（暖房時の室内平均相対湿度） への説明変数の影響度を比較するため, 標準化偏回㷌係数を算出し ている。気象条件を除けば, (1)室内発湿量, (2)吸放湿材の水分容量, (3)表面仕上げ材を含む見かけの水分伝達抵抗，(4)暖房設定温度，(5) 吸放湿材の面積の順に影響が大きい。

重回帰式（1）により室内湿度を計算すると，内装材に石暂ボード とパーライトボードを使用した場合では約 $7 \%$ 差が生じる。室内 湿度に影響しやすい要因を変更することにより，冬季の室内過乾燥 を効果的に改善できる。

$$
\begin{aligned}
Y=25.5 & +4.73 \cdot 10^{10} X_{A_{1}}+5.52 X_{A_{2}} \\
& -2.71 \cdot 10^{-6} X_{B}+5.47 X_{C}+1.41 X_{E} \\
& -1.22 X_{F}-0.483 X_{G}-1.25 X_{H} \\
& +8.00 X_{I}-2.20 X_{K}+13.9 X_{L}
\end{aligned}
$$

\section{5. 暖房時の室内湿度の簡易計算}

重回帰分析による暖房時の室内湿度の簡易予測式（1）の精度を検 証するため, 図 1 の住宅を対象としてパラメータ感度解析によるケ ーススタディを行う。対象室は 1 階和室と 2 階洋室 1, 気象条件は 東京・大阪・福岡とする。表 19 のように説明変数を変更して, 重回 州式（1）および THERBにより室内相対湿度を算出し, 両者の結果 を比較する (THERB の結果には冬季 1月〜2 月の暖房時において外 気相対湿度が $60 \%$ 以下のときを用いる)。

図 19 に, 重回帰式（1）と THERB による計算値を示す。重回帰 式は THERB と比較してやや小さくなる傾向にあるが, 最大でも $5.2 \%$ の誤差（G'-2）である。重回帰式（1）は暖房時の室内湿度の 簡易予測方法として十分な精度を有しており，簡単な計算ツールと して期待できる。ただし，重回帰分析に使用した建物モデルの断熱 性能は次世代省エネルギー基準の第吕〜第 $\mathrm{V}$ 地域相当であるため, 式（1）の適用地域は第吕〜第 $\mathrm{V}$ 地域に限られる。

\section{6. むすび}

本報告では戸建住宅の温湿度測定と数値シミュレーションにより， 冬季暖房時の室内湿度とそれに影響する各種要因の関係について検 討した。また, 熱・水分・空気連成を考慮した住環境解析ソフト THERB の計算精度を検証するとともに, パラメータ感度解析を基 にした重回帰式による室内湿度の簡易予測方法を提案した。得られ た結果を以下に列記する。

1）室内湿度は暖房時に $30 \%$ 以下の過乾燥になることが多く, 特に 外気温湿度が低い場合に著しく乾燥する。

2）壁体の吸放湿を詳細計算する THERB は，暖房時の過乾燥などの 室内温湿度変動を精度よく予測できる。

3）壁体の水分容量を室空気に加算して吸放湿の影響を近似する簡易計 算は, 絶対湿度変動が緩慢になり誤差が大きい。

4) 室内発湿量, 吸放湿材の水分容量, 表面仕上げ材を含む見かけの水 分伝達抵抗，暖房設定温度，吸放湿材の面積は室内湿度へ大きく 影響するため，それらの要因を変更することにより室内過乾燥を 効果的に改善できる。

5）重回帰分析による暖房時の室内湿度の簡易予測方法は十分な精度 を有しており，簡単な計算ツールとして期待できる。 
謝辞

本研究の一部は, 文部科学省科学研究費補助金 (基盤研究 (C) (2)) 「多成分連成系の熱・物質の複合移動現象と建築環境解析に関する 研究 (代表者: 尾崎明仁, 課題番号 16560527)」によるものである。

注

注 1） P-model はエネルギーと水分の保存則から成る非平衡熱力学モデルで あり，水分流の駆動力として応力の影響を考庿した熱力学エネルギー(水 分ポテンシャル $[\mathrm{J} / \mathrm{kg}(=\mathrm{kPa})])$ を用いることに特徽がある ${ }^{11 !}$ 。水分伝導 （材料内部の水分移動）と水分伝详（室空間および空気層と材料の間の 水分移動）を統一的に同次元で表現する（水分流は水分ポテンシャル勾 配のみに支配される) ため現象を理解しやすい。

注 2）多重共線性は，偏回㷌係数の符号と目的変数との単回㷌係数の符号の 逆転，および説明変数 $X_{i}$ の許容度で診断される。図 6 18 と表 18 に示 すとおり符号の逆転はみられない。また，表 20 に各説明変数の他の説明 変数に対する許容度を示す。許容度は $0.293 \sim 1.0$ の範囲にばらついてい るが多重共線性はない（重回帰分析に支障はない）と診断できる。 表 20 各説明变数の許容度

\begin{tabular}{|c|c|c|}
\hline \multicolumn{2}{|r|}{ 説明変数 } & 許容度 \\
\hline$A_{1}$ & 水分伝裂率 & 0.374 \\
\hline$A_{2}$ & 水分容典 & 0.366 \\
\hline $\mathrm{B}$ & 表面仕上げ検含む水分枟塏抵抗 & 0.967 \\
\hline $\mathrm{C}$ & 吸枚湿面穔/室容積 & 0.988 \\
\hline$E$ & 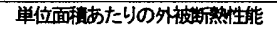 & 0.988 \\
\hline $\mathrm{F}$ & 換垁回数 & 0.977 \\
\hline G & 暖房甠間 & 0.998 \\
\hline $\mathrm{H}$ & 暖房設定鹖度 & 1.000 \\
\hline 1 & 室内発湿 & 0.965 \\
\hline$K$ & 外氛温度 & 0.293 \\
\hline $\mathrm{L}$ & 外気絶対湿度 & 0.297 \\
\hline
\end{tabular}

注 3）説明変数の選択について検討するため, 要因の $\mathrm{P}$ 值が有意水準（5\%) 以上であった水分伝導率掞よび単位面櫴あたりの外被断熱性能を除いた 9 要因を説明変数として重回帰分析を行うと，重相関係数は 0.98 , AIC は 3.10 となった。11 要因を説明变数とした 4.3 節の重回帰分析結果の方が, 重相関係数は 1 に近く，また AIC は小さいため,より精度が高いと䛦断 できる。

\section{本研究に関連する既発表論文}

1）香川治美，尾崎明仁：建筑温湿度環境の動的予測と調湿効果, 日本建築学 会環境工学委員会熱環境運営委員会第 35 回熱シンボジウム, pp.85-94, 2005.11

2）辻丸達憲，尾崎明仁，香川治美 : 建築温湿度環境の予測と調湿に関する研 究，日本建築学会九州支部研究報告·環境系，第 45 号 2, pp.273-280, 2006.3

3）寺島亮，尾崎明仁，香川治美：暖房時の過乾燥に影響する要因解析と室内 湿度の簡易予測, 空気調和・衛生工学会九州支部研究報告, 第 13 号, pp.17-22, 20065

\section{参考文献}

4）青木哲, 須藤千春, 水谷章夫, 大沢徹夫 : 室内温湿度環境とアトピ一性皮 庵炎, 日本建築学会環境工学委員会熱環境運営委員会第 35 回熱シンポジウ 厶, pp.69-72, 2005

5）西垣康広，鈴木憲司：消石灰及びぜオライトより成る調湿機能を有する新 規壁材の基礎研究, 日本建築学会構造系論文集, 第 588 号, pp.29-33, 2005

6）池田哲朗，今仲雅之：一戸建て住宅における韲開閉時の結露性状と吸放湿 材貼付効果，日本建築学会計画系論文集，第 473 号, pp.15-20, 1995

7）尾崎明仁：熱・水分・空気連成を考慮した建築の温湿度・熱負荷計算， Technical Papers of Annual Meeting of IBPSA-Japan, pp.19-26, 2005

8）次世代省エネルギー基淮解説書編集委員会 : 住宅の省エネルギー基準の解 説, 建築環境・省エネルギー機構， 2002

9）日本建築学会編：建築材料の熱・空気・湿気物性值，丸善，2001

10）石村貞夫, Desmond Allen：統計用語，東京図書，1997

11) Ozaki A., Watanabe T., Hayashi T., Ryu U.: Systematic Analysis on Combined Heat and Water Transfer through Porous Materials Based on Thermodynamic Energy, Journal of Energy and Buildings, Vol. 33, No. 4, pp.341-350, 2001

(2006年 8 月 7 日原稿受理，2007年 3 月 9 日採用決定） 